

\title{
Ingesting Magic: Ingredients and Ecstatic Outcomes in the Greek and Demotic Magical Papyri
}

\author{
ALAN SUMLER
}

HOW DID ANCIENT MAGIC WORK?

PUT ANOTHER WAY: if ancient magic didn't work, then why was it a standard practice for such a long time? Although nearly impossible to answer, the following essay attempts to understand the expected and actual outcome of magic for the practitioner or client with regard to certain spells found in the ancient Greek and Demotic Magical Papyri. To unravel the mystery, we must journey through modern chemistry, ancient pharmacology, ancient medicine, the ancient drug trade, and into the very spells themselves, along with the worldview of their users.

I consider spells that boast large outcomes and offer big promises to the client. These outcomes include instant visions, states of ecstasy, communion with a god, divine assistants, prophetic dreams, and long hypnotic episodes.

Before unraveling spells, some preliminary items must be explained. The collection of magical spells needs context, the worldview of ancient magic. Modern-day scientific understanding of the ingredients in the spells is part of the key to unlocking them; at the same time, the ancient pharmacological and medical outlooks ultimately reveal the true power behind the magic. ${ }^{\mathrm{I}}$

THE ANCIENT GREEK AND DEMOTIC MAGICAL PAPYRI AND THE WORLDVIEW OF ANCIENT MAGIC

THE COLLECTION of papyrus scrolls, written in ancient Greek $(P G M)$ and Demotic (PDM), is somewhat a mystery itself. The material it contains was banned in Late Antiquity, beginning in the reign of Constantine the Great (fourth cen- 
tury AD), intensifying under the Theodosian Code (429 AD), and lasting through the Middle Ages. Practicing magic and books about the practice were considered subversive and anyone in possession of them could face serious penalties. In many instances books about magic were burned.

The autobiography of Libanius (a fourth century AD rhetorician who lived and worked in the Eastern Roman Empire) constantly describes court cases against him by his political enemies under the charges of practicing witchcraft and he often notes how he had to call his magical providers "doctors" so that suspicion was not raised, though he considered that magicians had the only effective cure for his gout. There was, then, a challenge by Church medicine to pagan magic, requiring the client to use medicinal-sounding terminology and to avoid magical terms. Pagan practices ultimately died out and their core magical texts were lost forever, while the ingredients used in magic would continue to be used as a mainstay in medicine and pharmacy, practices and plants likely going back to prehistorical humans.

It is a marvel that we possess the collection today. It survived, hidden under sand, scattered throughout the deserts, lost in temples of Egypt, for almost a thousand years. It emerged again in the nineteenth century, found under unknown circumstances and sold piece by piece to collectors of antiquities. Two diplomats, collecting ancient texts, bought the various scrolls in Egyptian marketplaces. The scrolls were ultimately auctioned off to different museums and university collections. Over time scholars began to take the collection seriously and a full version of all the scrolls appeared in the twentieth century along with an English translation. The different spells range in date of origin, roughly from the second century BC to the fifth century AD. Since the collection emerged, scholars have devoted serious attention to interpreting it, not so much looking for the genie in the bottle, but the rationale behind the spells and the outlook of its practitioners. ${ }^{2}$

The collection can be divided into different types of spells and various pieces of sacred knowledge. Within it, we gain 
great insight into ancient religious, magical, spiritual, medical, and recreational practices. Besides standard magic like binding, divination, and attraction, it also contains hymns to the gods, rituals for worship, and temple liturgies. It gives a microscopic view into ancient religion and contains information about the personal practice of magic.

The traditions of ancient religion and magic were shared and they informed each other. The collection of spells as well as other items were used by magicians and temple attendants. Magic and religion were related; they were different sides of the same coin. For instance, fumigations, i.e., the burning of potent herbs on altars, were used at civic festivals, assembly meetings, and religious mysteries. At the same time, spells in the collection constantly demand that the user employ fumigations for personal and private rituals. The names of the gods and goddesses used at the public festivals are in many ways the same names used in the magical spells. Pliny, for instance (Natural Histories $25 \cdot \mathrm{I}-\mathrm{I} 8$, I ${ }^{\text {st }}$ century $\mathrm{AD})$, mentioned that the gods and goddesses are to be given credit for their discovery of potent herbs.

We can think of religion as publicly divine events, shared experiences in festivals and temple worship. Magic is more private and deals with spirituality, personal needs and concerns. The practitioner or client seeks answers, divine assistance, divinations, and prophetic visions through burnt offerings, incantations, magical items, and ingestion of specified ingredients. The magician is well-trained in divine arts and clients seek him out for answers to their problems and for help in learning the art.3 For many of the spells in this essay, the magician sold the user the spell, gave him special instructions, and then the user bought the ingredients from the market place. Other spells were performed by the magician or amateur magician in order to increase their own divine powers.

The spells in the collection have different uses and applications. Some spells inform the magician of magical practice or the temple attendant of temple practice with respect to 
botanicals and other procedures, for instance, picking herbs or singing incantations. Other spells have a more practical, immediate end: love attraction, binding spells (with different outcomes, for instance throwing the results of a chariot race), business spells, divine bidding (sending a spirit to do your work), divine assistants, nefarious deeds, prophecy, and medical treatments. There are even spells consisting of party jokes, practical jokes, and parlor tricks.

The spells have distinct parts: logos (names, incantations, figures) and praxis (preparations, ingredients, and procedures). The user would enchant certain names and incantations, write down magical symbols and drawings, make a burnt offering, and ingest some of the ingredients, all with a certain outcome in mind. We should understand that the outcome of a spell is not always clear to us.

Ancient medicine, religion, and magic have their own rationale as to why something works or what belongs to a certain practice. For magic some rationales have been theorized, including the concepts of sympathies (similarities, i.e., like works on like, like attracts like, or similia similibus), antipathies (contraries, unlike repels unlike, or dissimilia dissimilibus), and contact (things touching each other exchange properties). It is assumed that every plant, animal, or stone has a power (dynamis) and that this power can be manipulated by the user for the user's own benefit. Accordingly, items are combined and used or names enchanted under these different associations. There is a sympathetic correspondence between natural materials, i.e., choice of ingredients, divine forces, and expected outcome. Other sympathies between different items and powers appear in the spells. Ancient pharmacology and medicine supplied their own rationales concerning the power of plants but built upon the ones already established in magic and religion.

Let's see these magical sympathies at work in a specific spell: PGM I3.I-343, called "Unique" or the "Eighth Book of Moses." The practitioner uses this spell to initiate himself into the realm of the gods so that he can communicate and 
ask things of the gods. After initiation, he can use the spell for numerous specific outcomes: to become invisible, to attract a lover, to make someone unattractive, to get rid of unwelcomed demons, to rid someone of disease, to cure a bone fracture, to kill a bird, to break other spells, to speak to Helios, to kill a snake, to resurrect a dead body, and more.

Most of the spell explains the process and materials needed for initiation. The practitioner must remain pure for forty-one days and be ready for the initiation at the new moon. He sets up an altar and burns different types of incense on it. Three figurines are made out of flour and water, fumigated, prayed over, then eaten (one bull-faced, another goat-faced, and another ram-faced). In addition, a brick of natron (sodium carbonate) must be inscribed with sacred names, a prayer, and two figures (a falcon-faced crocodile with a god standing on its back and a snake eating its own tail). The practitioner has a sheet of metal (a sacred stele called "Key of Moses") with all the appropriate names, figures, and incantations, which I assume he bought from the magic shop or was supplied by his mentor. The ink used for the natron brick consists of a mixture of prepared botanicals (incense and flowers) and the user will lick the ink off the brick before the ceremony is over.

The practitioner is instructed to gather and have all these items for the ceremony: a tripod made of laurel root, the botanicals (dried flowers and incense), sacrificial animals, a knife for sacrifice, honey, milk, wine, and something upon which to write down the god's response. The practitioner must wear clean linen on his body and an olive wreath on his head. He builds a canopy (a tent) in which to perform the ritual and upon this canopy he writes the names of the threehundred and sixty-five gods which represent each day of the year. Within this tent, he will burn incense and undergo the initiation or desired experience.

The sympathies come into play with the ingredients. In the spell, seven different kinds of incense are aligned with specific gods and goddesses. These pairings come from a sacred 
text of Hermes called "Wing," which the scribe cites. The god Kronos matches up to storax, Zeus to malabathron, Ares to kostos, Helios to frankincense, Aphrodite to Indian nard, Hermes to cassia, and Selene to myrrh.4 The spell lists seven flowers which align with seven stars. These items are combined and used for different purposes and outcomes.

The rationale behind the spell is that the substances are similar in some way to the gods and stars. If they are used in certain proportions, the power of the gods may be harnessed. The practitioner must be aware of the day and hour during which he uses the spell and its parts. He has to call on the correct god or goddess and use the correct incense and dried herbs which correspond. If done correctly, the god will tell him things about himself, i.e., the one being initiated, and give him a name. The practitioner cannot leave the tent until the god appears and speaks.

In the spell there is a sympathetic correspondence between the gods and goddesses, the types of incense and flowers, and the stars in heaven. The list of usages at the end of spell show other sympathies and antipathies. For instance, to get rid of a demon, apply sulfur to his nose and the demon will leave. Sulfur smells horrible and should be used to rid the possessed person of something horrible, i.e., the demon. The different effigies in the spell also reveal sympathies. A figurine or drawing of the god makes the god appear and interact with the practitioner.

The true experience in this spell occurs inside the tent, when the practitioner is burning psychoactive substances, licking ink (made from the same substances) from the natron brick, and drinking wine (which had more psychoactive substances in it). This is evident by the advice in the spell to not leave the tent until the voice occurs. It ensures that the client has ingested enough of the psychoactive substances to feel the effect and thus the magic.

Another spell, PGM I2.4OI-44, gives code names for different herbal and animal ingredients. The list comes from temple attendants and these ingredients were inscribed on 
the statues of gods: they correspond to the statues in a sympathetic way, i.e., according to the power of the god or goddess and the ingredient aligning with their power. The spell warns the readers that those inexperienced in these ingredients can harm themselves and others; and for this reason code words were employed.

Many of the ingredients in the spells are not given a dosage or weight. The user had to know how to get the ingredients and ascertain their potency, their dosage, and overdose risk. When a root cutter picked powerfully smelling herbs, he would cover himself in powerful smelling potent herbs as an antidote to the effects of harvesting potent herbs, a dangerous and specialized task.5 The procedure for root cutting is an example of antipathy, unlike repelling unlike.

A final example of sympathetic correspondence between a specific botanical ingredient and a god may be found in PGM I.42-I95, which I cover below in greater detail. In it, the plant heliotrope is used because the spell concerns the god Helios, thus like attracting like. The sympathetic relationship between the ingredients and the outcome of the spell as well as the true application of the spell are, naturally, not always clear to the modern reader.

\section{ECSTATIC STATES, DRUG DEALERS, AND ANCIENT PHARMACOLOGY}

ANCIENT MEDICAL and pharmacological texts cover psychoactive substances and what outcomes they produce. Their pharmacology is concerned with potency, purity, drug tolerance, and overdose. (Modern-day botany confirms that these ingredients are psychoactive, for instance, opium, wormwood, mandrake, henbane, nightshade, hellebore, and many others. ${ }^{6}$ These ingredients were used in ancient medicine, including Egyptian and Babylonian, as well as in European medicine beyond the ancient world.)

We begin with medical terminology from the Roman doctor Galen (third century BC). An entry in his corpus (Pseudo- 
Galen, Definitiones medicae I9.462) defines enthousiasmos, i.e., experiencing ecstasy or inspiration from a god, as an altered state of consciousness: 7

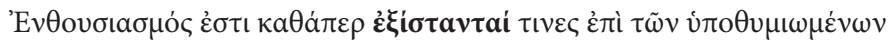

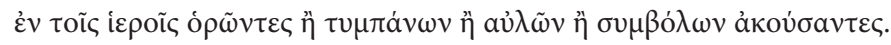

Enthousiasmos is the same as when some people go out of their senses after the fumigations when they look upon the sacrifices or hear the tympani, flutes, or cymbals.

The extra-sensory experience is induced by exposure to the smoke of burning incense and hypnotic music. ${ }^{8}$ It is a welcomed religious experience to the participants and it occurred because the smoke was psychoactive.

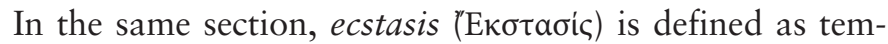

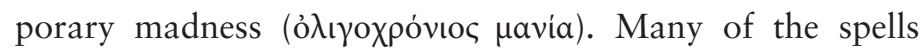
require that the user undergo an ecstatic experience or mania. 9 The ingredients, according to the Roman pharmacist Dioscorides (first century AD), in his De materia medica, would produce such experiences, which, for one item, nightshade, he describes as not unpleasant (I4.73.2). ${ }^{\text {Io }}$ Pliny (Natural Histories 25.2 I,) writes that intellectuals of his time would use the psychoactive plant hellebore for recreation and mood enhancement.

The fumigation of incense is important for both public and private religious experiences. It is often referred to in the magical collection and occurs anytime some ingredient is burnt and then inhaled: spells typically ask the user to burn incense or to incense an item. Fumigations occurred before the Athenian assembly meetings in order for the participants to feel the presence of the gods. ${ }^{\text {I } ~ W h e t h e r ~ t h e s e ~ f u m i g a t i o n s ~}$ occurred outdoors or inside, the ancients knew to inhale the smoke and feel its effects, and associated the magical smoke with divine experiences. Some of the spells in the collection ask clients to put face or mouth over the smoke, in case no one taught them to inhale.

The fumigation of psychoactive substances, i.e., materials which change the chemistry of the mind and the conscious- 
ness of the user, were necessary for the desired outcome of certain magical spells. We find promises in the spells of these immediate experiences. I cover here two instances of the expectation of an immediate experience. ${ }^{\mathrm{I} 2}$

PGM 3.I-I64 is a binding spell for throwing a chariot race, amongst other things, and requires the drowning of a cat. The practitioner submerges the cat in water, while saying a prayer. With cinnabar ink the user prepares a sheet of papyrus, writing details about the chariot race. ${ }^{13}$ The cat is wrapped in the papyrus and then buried. While burying the cat, the user makes a burnt offering. At lines 23-24, the spell instructs: "fumigating storax gum to it, be of good cheer"

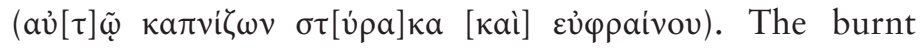
storax gum, a psychoactive ingredient typically found in ancient incense, would directly influence the practitioner's mood and produce "good cheer" for attending the chariot races. After burying the mummified cat, the user takes water from the cat's drowning and sprinkles it on the track. The spell relies on the dead soul of the cat or the demon associated with the dead soul of the cat to do the bidding of the client and to throw the chariot race.

PGM 4.850-929 is a spell called the Charm of Solomon and it is supposed to produce an immediate trance

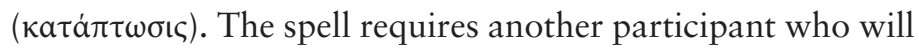
actually go into the trance and answer questions for the client. It is assumed that the one in the trance communicates and hears the god who answers specific questions. The induced state begins after the user fumigates frankincense. Other items present for the offering include beer, wine, grapevine wood, and wormwood.

Ancient pharmacology recognized that these substances were very potent and could produce such results, i.e., hallucinations and ecstatic states. Theophrastus (fourth to third century BC) wrote book nine of his Inquiry into Plants on the pharmacological properties of plants. (Theophrastus, head of Aristotle's Academy and student of Aristotle's, had the "inside scoop" concerning psychoactive substances: Athenaeus [Deip- 
nosophistae, $8.354 \mathrm{~b}$, second to third century $\mathrm{AD}$ ], while quoting the ancient Greek philosopher Epicurus [fourth to third century BC], wrote that Aristotle was a drug dealer

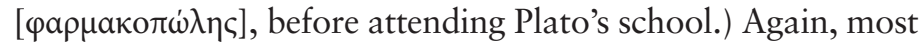
of the ingredients for the spells, like the ingredients for medicine or temple practice, were bought in the market from drug dealers. It should be noted here that these same ingredients were commonly added to wine in order to increase its potency, which is said to have been about $8 \%$ alcohol. ${ }^{\mathrm{I}} 4$

Theophrastus knew that many of these substances affect one's mental status. He writes (Historia plantarum 9.I9.I):I 5

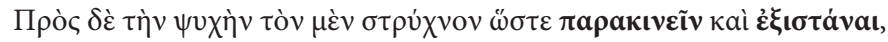

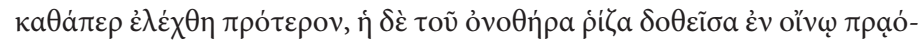

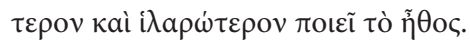

And as to (drugs that affect) the mind, nightshade makes it so that one is maddened and ecstatic, just as I said before, the root of oleander mixed in wine makes (one's) mood more mild and cheerful.

The word for ecstatic (existanai) is the same word used by Galen (existantai) in his description of trance-like experiences at the fumigations. Dioscorides also indicates which drugs alter the mind. Sometimes the outcome is a treatment for the patient, other times it is considered a side effect of the treatment. Pliny (25.7) always mentions the psychotropic effects of plants, but he refrains from explaining the magical applications and the visionary properties. In his opinion, there was no curative benefit in magical practices.

Dioscorides, Theophrastus, and Pliny cover the adulteration and purity of botanicals. When discussing the purity of balsam, Theophrastus remarks about all botanicals in Greece: "and what is often found in Greece has been adul-

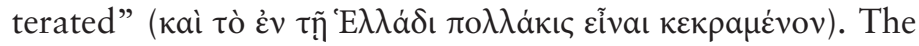
medical professional or client at the marketplace needed precise knowledge about botanicals in order to buy the correct ingredients with the correct potency and purity.

Theophrastus (9.I7.I) gives us an image of drug dealers in the marketplace with people, especially shepherds, trying to 
discredit their products as not being potent. He concludes that the customers had built up a tolerance to the effects of the botanicals.

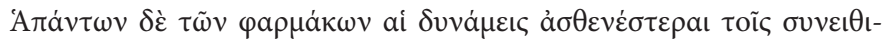

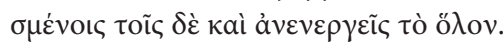

The power of all drugs becomes weaker for those who are habituated and for some people at times they are ineffective. ${ }^{\mathrm{I}}$

As he explains, shepherds would discredit the drug dealers by eating their products at the stand and then suffering no effects from the drug. The users had built up a drug tolerance over time to the products, and the dealers had to understand this tendency with drugs so that their clients did not take advantage or discredit them. Drug dealers were a permanent fixture in all ancient market places and they also sold luxury items like perfume, make-up, and incense. ${ }^{\mathrm{I}}$

The drugs themselves were expensive, especially the ones that appear in the magical spells for visions and ecstatic experiences. ${ }^{18}$ The different psychoactive botanicals found their way into the cities through multiple routes and vendors, including itinerant pharmacists, root cutters, drug dealers, and the incense and spice trade, which covered Africa, Asia, and Asia Minor. ${ }^{19}$ According to one scholar, people using these spells would literally have "money to burn." 20 They were a luxury and a recreational activity, though one might consider some of these visionary spells as entertainment and others as a sleep aid. In the former case, they took the user on an interesting journey but may also have made them feel better, with some medicinal benefits.

OPIUM, MANDRAKE, HENBANE, AND EVIL SLEEP

THE FOLLOWING spells promised a very obvious and sudden physiological outcome. A handful of spells in the PDM give instructions for causing either an "evil sleep" (for instance, PDM I4.675-94, 7II-I 5, 9II-I9) or a deep sleep (PDM I4.7I6-24, 727-36). These are prescriptions for drugging 
somebody. We expect to see powerful ingredients for these spells, since they promise such an obvious outcome: either sleep or a prolonged catatonic state. The spells contain the kind of ingredients that would have provided such powerful results. Each one involves combining a series of potent items and making them into food or serving them in wine.

What does it mean to "evil sleep" a man? On the surface, i.e., literal sense, it means to put someone out, likely for nefarious reasons, perhaps in order to rob them. Many of the spells in the collection have such nefarious ends. At the same time, I wish to consider a different approach to the literal interpretation; it is possible that these spells, for instance to "evil sleep" a man, may have other applications and meanings to the practitioner of magic.

According to Diogenes Laertius (section 5.6, third century $\mathrm{AD})$, Aristotle died after drinking aconite or aconitum (wolf's bane), a deadly psychotropic botanical, used as arrow poison and animal poison. Why would he drink arrow poison?2I According the ancient poet Nicander (fourth century BC), aconite (Alexipharmaca 207-23) and hemlock (Alexipharmaca I86-94) were taken recreationally in smaller doses. Any substance that was toxic at one dosage could be taken in lesser quantities with lesser effects. In this sense, to "evil sleep" someone is akin to a recreational advertisement, a long hypnotic episode, perhaps religious in nature. Consider the name of a popular craft beer in Colorado called "Wake Up Dead," which boasts a high alcohol content of $10.2 \%$. Who would want to wake up dead? Not all is what it seems on the surface. Let's see how the following two spells work.

PDM I4.7II-I 5 (Column 24, I-5) requires I dram or drachma of opium, I dram of scammony root, and milk. ${ }^{22}$ The mixture is turned into a ball and put in food. Once eaten, the result: "He is upset" (tr. Johnson in Betz I992, 233). Opium is a powerful narcotic with deeply felt effects when ingested. The spell is a "tested prescription" to "evil sleep" a man. Many spells boast of their efficacy. 
It is no surprise that Dioscorides (4.64) lists different types of opium poppy $(\mu \eta \dot{\kappa} \kappa \omega)$, each one with soporific properties and different medicinal applications. It was by far the most commonly used drug in the ancient world. ${ }^{23}$ The Demotic spell does not give any details as to what kind of opium, although it asks for juice. Dioscorides $(4.64 \cdot 3)$ writes that the juice (ómòs), when consumed, takes away pain

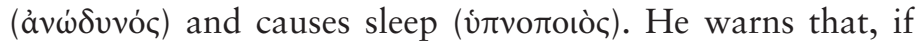
too much is taken, it causes coma ( $\beta a \pi \tau i \zeta \varepsilon\llcorner<u ̈ \pi \nu \omega>$

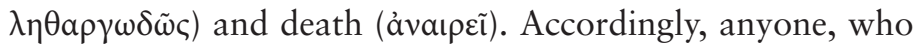
wanted to "evil sleep" another person or himself must get the dosage correct. ${ }^{24}$

PDM I4.7I6-24 (Column 24, 6-I4) uses different ingredients - I ounce mandrake root and I ounce henbane-but equally potent. This spell promises two days of sleep, so it must be rather powerful. The ingredients are meant to be clarified and taken in wine. Just as the previous spell advertises that it is tested, so this spell ends with the promise: "It is very good" (tr. Johnson in Betz I992, 234).

Dioscorides (4.75) writes about mandrake ( $\mu \alpha v \delta \rho \alpha \gamma$ ópac) and its effects on the user. Shepherds $(4 \cdot 75.2)$ eat the fruits

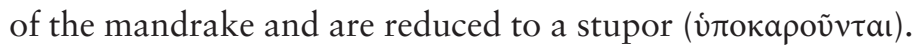
The root $(4.75 .3)$ is typically boiled down, i.e., clarified, with wine and used to treat insomnia (à $\gamma \rho v \pi v o v i v \tau \omega \nu)$ and heavy pain $\left(\pi \varepsilon \rho\llcorner o \delta v v \omega \dot{v} v \tau \omega v) .{ }^{25}\right.$

Most surprising, the root, when prepared this way, can be used to put someone under, i.e., used as an anesthetic

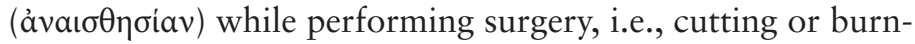
ing. He later explains $(4 \cdot 75 \cdot 5)$ that mandrake root works for surgery, because the patient falls into a deep sleep ( $\delta$ ıà tò

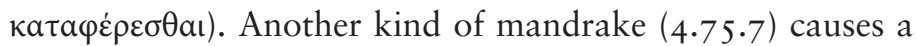
person to fall asleep ( $\kappa \alpha \theta \varepsilon \dot{\delta} \delta \varepsilon \iota)$ at the very moment of consumption, and the deep sleep, where they feel nothing

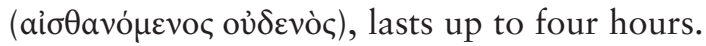

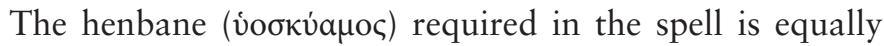
powerful. Dioscorides (4.68.2) writes that the different kinds

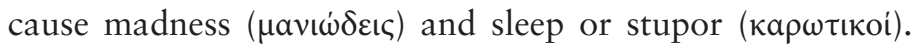


The juice of the seeds $(4.68 .3)$ is better than poppy juice and a powerful painkiller (å $v \omega \delta v v \omega \dot{\tau} \varepsilon \rho o v)$. If the leaves are boiled

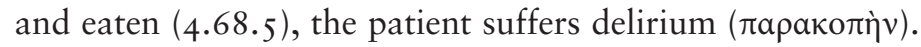
Henbane and mandrake combined would cause a person to sleep for two days, as the spell promised. ${ }^{26}$

These two spells show us that the client expected immediate results from the procedure and that the ingredients play a significant role in making the magic occur.

The following spells have powerful ingredients and ecstatic outcomes. Each one requires psychoactive ingredients and comes with its own promise of efficacy. The client would expect immediate results with these spells as well, i.e., hallucinations or vivid dreams.

DREAMS, ATTRACTION, AND A DIVINE ATTENDANT

“THE SWORD OF DARDANOS," PGM 4.I7I6-I 870,27 is a spell for the attraction of another person, possibly for erotic intentions. The spell has one part for acquiring a divine assistant to help complete the spell. The assistant will attract the desired person and send dreams. The spell has a list of ingredients to be combined and made into a burnt offering, i.e., fumigated. The procedure promises a certain outcome: "It immediately bends and attracts the soul of whomever you wish" (tr. O’Neil in Betz I992, 69).

The user takes a magnetic stone and engraves Aphrodite sitting on top of Psyche and an Eros along with sacred names and letters. The stone is put under the tongue as the user enchants a spell. A magical formula is inscribed on a golden leaf. The gold leaf is fed to a partridge and then the user kills the partridge. The spell instructs the user to wear the dead partridge around the neck.

Next, the spell describes the ingredients for fumigation, beginning at line I 826: "Here is the burnt offering which en-

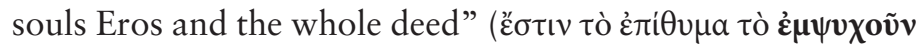

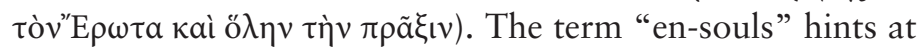
the magical intoxication of the spell. The potent list includes 
4 drams manna ( $\mu a \dot{v} v \eta \uparrow$, frankincense powder), 4 drams

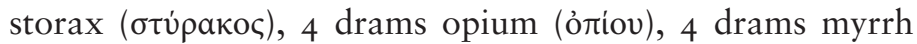
( $\sigma \mu \dot{\rho} \rho v \eta \varsigma), 4$ drams frankincense ( $\lambda i \beta a v o \varsigma), 1 / 2$ dram saffron (кро́коৎ), and $1 / 2$ dram bdella $(\beta \delta \dot{\varepsilon} \lambda \lambda \alpha)$. The ingredients are mixed with dried figs and wine, then fumigated.

The spell asks the client to set a table and sit with an effigy, while burning the offering. The effigy is made out of mulberry wood and is in the form of a winged Eros. Another gold leaf is inscribed with the name of the one being attracted and put into the effigy. Besides the one being attracted, the user writes the name of the divinity, which will assist, thus binding the two.

Before the fumigation and table setting at home, the user must visit the person's house with the effigy of Eros. He knocks on the door and says to the effigy that the person being attracted lives there. The client then goes home and completes the ritual with the table, fumigation, incantation, and the effigy. It instructs him afterward to go to sleep and, if the spell is successful, a dream is sent.

After inhaling the ingredients, a dream state was very likely. This spell has four times the amount of opium in addition to the same psychoactive ingredients as the spell above for "evil sleep." In the event that no dream occurs, the spell assures the client that the divine attendant is busy with other work (line I87I). The dream may have occurred, but the user slept so deeply that it was forgotten. Other spells give a procedure for not forgetting the dream vision.

Dioscorides has an entry for each of these ingredients. All of them are used as different types of medication. Frankincense

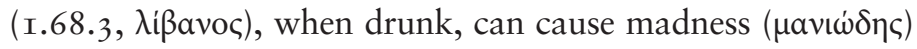

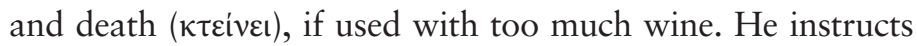
the reader ( 1 .68.2) how to tell if frankincense has been "cut"

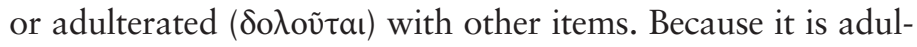

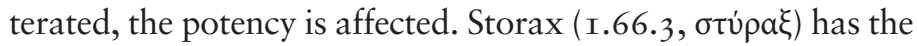
same effects and applications as frankincense. Its effects are

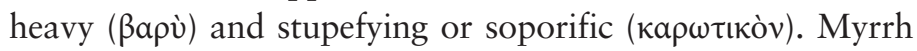




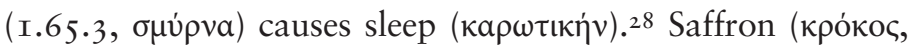
I.26.3) in a dose of 3 drams mixed with water is poisonous

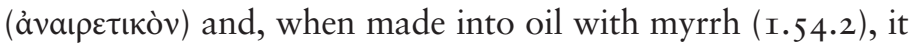
is soporific or narcotic ( $\dot{v} \pi v \omega \tau \iota \kappa \eta \dot{v} v)$.

After the user mixed these ingredients and burnt them, a deep sleep and dreams were very likely. All the ingredients were capable of causing sleep and sending the promised dream. It is unclear whether the person designated to come in real life, i.e., be attracted, would actually come. Perhaps, after the user slept on the subject, the issue became clearer.

One possibility: after the client knocks on the door of the one being attracted, the one being attracted may spot the client and later seek him out, thus the spell completely coming true. Otherwise, the dream state caused by inhaling the ingredients seems to be the main desired outcome of the spell. Busy spirits might serve as a good personal excuse for someone's ill-success at love.

\section{NIGHTSHADE, ECSTATIC VISIONS, AND COMMUNION WITH A GOD}

PGM 2.I-64 Is a spell for communion with Apollo. It requires preparation and application of psychoactive botanicals, speaking incantations to a lamp, writing a spell on laurel leaves, and drawing the "Headless One" on a strip of papyrus.

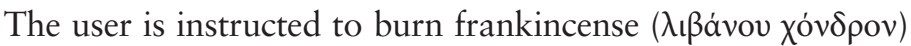
in a lamp as he goes to sleep with the laurel leaves and papyrus strip placed beside the head. He also burns uncut frankincense ( $\lambda$ ißavov ä $\tau \mu \eta \tau o v)$ in addition, while lying in bed.

So that he remembers the divine experience, he makes a compound and applies it before sleeping. The compound

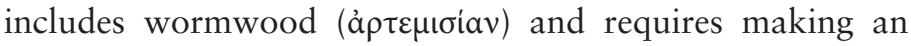
ointment which is applied to the lips. Before the application, the user is instructed to burn frankincense gum ( $\chi$ ó $\delta \rho \omega$ $\lambda_{\imath} \beta$ ávou) into his mouth.

As with most spells in the collection, magical names and symbols must be written down and recited. The client recites 
them while holding twigs of laurel. The bed must be purified and set up in a certain way and direction. The procedure occurs right before going to sleep and must be done at certain times during the month. After the fumigation, the spell instructs the user to give answer to "nobody," an indication that he is already hallucinating and hearing voices, as he performs the ritual. He wears a garland of laurel and other ingredients on his head and will hold it as he sleeps. Each of these items, made of laurel, represents Apollo in a sympathetic way.

A recipe for myrrh ink is given for writing down the names

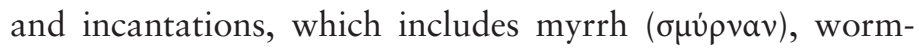

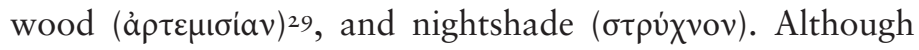
the ink is used for writing down incantations from the spell, the instructions require the user to put some of the ink into the ear.

If the user has trouble remembering the communion with Apollo, then some magical characters must be written with the ink on a leaf of cinquefoil and put it in the mouth while sleeping. Cinquefoil ( $\pi \varepsilon v \tau \varepsilon \delta \dot{\alpha} \kappa \tau v \lambda o v)$ is also used for preparing the ink. ${ }^{\circ}$ It is interesting that this spell requires two different applications of ingredients for remembering what Apollo says or to "achieve a good memory."

Dioscorides describes $(4.72,4.73)$ two types of nightshade ( $\sigma \tau \rho \dot{x} \chi v o v$ ) and the spell does not specify which one is used. Both kinds are very potent and psychoactive. Sleepy night-

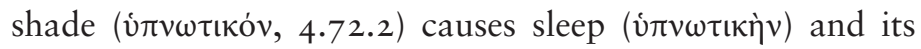
effects are less than that of the juice of opium. If too much is

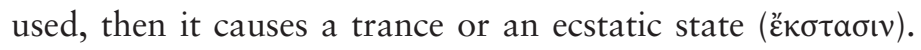
The other kind ( $\mu$ avıкóv, 4.73.2), thorn apple, when taken

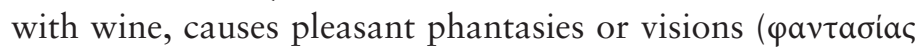

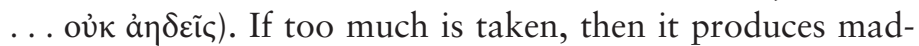

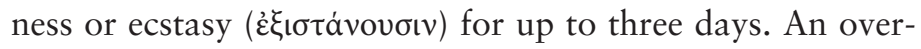
dose will cause death (ávaıpoũoıv) and an antidote is administered to induce vomiting. ${ }^{3 \mathrm{I}}$

The different ways of ingesting these psychoactive substances would ensure some magical outcome for this spell. 
By the time the user had the promised experience, he had inhaled three different preparations of frankincense, anointed the lips with wormwood, and put myrrh ink (myrrh, wormwood and nightshade) in his ear and mouth. The desired divination with Apollo occurred with vivid dreams while the user slept.

The magical rationale behind these ingestion methods would follow the concept of similia similibus, like things attracting like things, and contact, things touching affect each other. Putting the items in the ear allows the client to hear the deity. The inhalation brings the god into the soul, and the lips allow for communication.

In the event Apollo does not appear, the spell contains further instructions for making different sacrifices. If appearance hasn't occurred by the fifth day, even more magic is required. The spell ends with even more procedures, if the ones already used did not work. It seems that Theophrastus was correct when he wrote that good unadulterated frankincense and pure botanicals in general were hard to get in Greece.

\section{FUMIGATION, HALLUCINATION, AND A DIVINE ASSISTANT}

SOME SPELLS promise very grand results. PGM I.42-I95 is a spell for acquiring a divine assistant. Called the spell of Pnouthis, it comes with an impressive lineage and preamble about its effectiveness. The assistant will persuade all the gods and goddesses. The spell requires psychoactive ingredients.

The user, after preliminary purification, while wearing a clean garment, recites a spell to the setting sun, while holding a falcon head in one hand and with eyes covered. When the sun rises, he burns uncut frankincense and rose oil and says another spell.32 After the fumigation, a sign is immediately promised. A falcon flies down and deposits a stone on which the user will inscribe magical items described later in the spell. The falcon immediately flies away. The user is now hallucinating, with eyes covered, as the vision occurs. Whether a falcon immediately appears is unimportant, so 
long as a stone is found on the floor afterwards (the ritual takes place on the roof).

After the preliminary incantation, on the next evening, the user is instructed to burn myrrh Troglitis, while holding a branch of myrtle, and again a sign immediately appears: a falling star and an angel. The stone, which was found, hangs around the neck with its engravings. According to

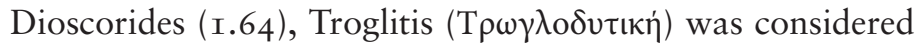
the most potent myrrh available to purchase and we can assume it was very expensive.

The user and the angel are supposed to sit down and have dinner and communion together. The divinity is now the assistant and the spell has multiple uses with the assistant. It is interesting to note that the first meeting with the divine assistant only lasts three hours, as if the substance stops having any effect after that time.

At this point the spell is exceedingly unexplainable. The second session or meeting demands the employment of a servant boy for the dinner and communion. I suppose the user wears the blindfold for each session. In other spells, the secondary person also inhales the fumigation and shares in the hallucination. At one point, the servant tells the divinity to go away, but we do not suppose he wears a blindfold or shares in the episode with the user. But this part of the spell is not the most fantastic.

The list of tasks which the assistant can perform is impressive. The divine assistant will send dreams, answer direct questions, i.e., divination, bring women and men, kill people, and change the weather. These tasks are standard practice in ancient magic and for divine assistants. The spell goes on with other items, so unreal that the writer of the spell will comment at one point about the user's expectation.

The spell continues with tasks which include bringing gold or silver, freeing people from prison, opening doors, causing invisibility, and bringing food. The spirit will go so far as to set up and provide for huge, lavish banquets, complete with walls covered in marble. At this point in the spell the scribe was compelled to 
add an interjection, "and you consider these things partly real and partly just illusionary” (lines I IO-I I, tr. O’Neil in Betz

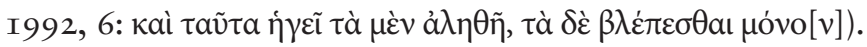

Taking into account the scribe's interjection, the spell achieves all that it promises. The user, blindfolded, would sit for three hours inhaling frankincense or myrrh and achieve communion with a deity, i.e., hallucinate. The tasks listed in the spell are likely events envisioned during the communion and things that he hoped to occur in real life. The spell tells the user to perform the rite as many times as needed and for as many purposes as one wants.

The final use of the assistant is for prophecy and fortune telling. The assistant will even help out after the user has passed away, guaranteeing his ascent to heaven. With such impressive outcomes, even if half-real, the user must have received some benefit and experience from the ritual. Constant use of the substances and the incantations allowed the user to envision his life-needs and try to fulfill them. On the literal level, the spell is impossible, but on the spiritual level all is well and working. It is possible that the servant boy is present to babysit the user on his journey. If it gets too intense, the servant can calm him down-i.e., ask the god to exit.

\section{ATTRACTION, DIVINE ASSISTANT, AND DREAMS}

PGM 4.244I-62I has an even more impressive guarantee of its value and results. The spell is for attraction and it supposedly works in one day. Besides attraction, it has other applications: the spell can send dreams and visions to the user; it also has nefarious ends. Before the list of ingredients, the spell boasts that the Roman emperor Hadrian (reigned I I 7-38 AD) bought it, used it, and enjoyed it so much that he doubled the magic dealer's pay-that was Pachrates, the prophet of Heliopolis.

The list of ingredients (beginning at line 245 I) includes 2

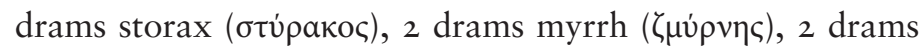




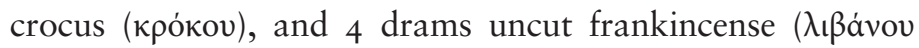

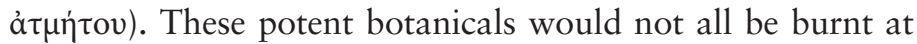
once; they are stored in a box for many uses. Other items in the mixture include a deified mouse, beetles, crab, and fat from a goat. When the client needs to use the spell, they are instructed to go onto the roof and burn the offering at night. The result (lines 2466-467): "at once she comes" ( $\pi \alpha \rho \alpha \chi \rho \tilde{\eta} \mu \alpha$ $\left.\eta \eta_{\varepsilon \iota}\right)$. The psychoactive ingredients in the burnt offering were integral in producing an immediate and instant result for the user, who first gains a divine assistant through the procedure.

After inhalation of the substances, a deity appears who will either find the one to be attracted or send dreams and prophecies. There is a safeguard in the spell, in case the one to be attracted does not ultimately come. I assume the meeting with a deity would occur as a hallucination or dream vision. The spell warns at line 2495 that the user must open the door so that the one attracted will enter, otherwise the spell will fail. (After heavy usage of the offerings, the user may forget or be unable to open the door.) Whoever is supposed to come may also have appeared in the user's dreams.

Specific applications of the spell are nefarious: for example, the assistant can cause others to be sick and to die. The user is instructed to have a protective charm against the divinity because the divinity tends to harm the user of the spell. The nefarious side of the spell continues with different incantations for coercion and hostile intent. Here, again, a warning against using the spell: only call upon the forces of Selene for important matters. Although the details of this spell are the most difficult to explain, as to real outcome, some speculation is possible. Just as the previous spell allowed the client to meditate upon things wanted in life, good things, so this spell allows the client to focus upon wicked things and hope for an outcome. The only part of the spell that can explain Hadrian's enthusiasm, although that is seemingly made up, would be the ingredients and their potency. He likely had the vision quest and loved it. He certainly had access to all good ingredients. 35 
THERE ARE many more spells in the collection having interesting ingredients and outcomes, and they are shorter and less complicated; I cover a few of greatest interest here. The following spells are for visions and dreams. Many occur at night or use lamp divination. Each one uses either frankincense or myrrh and at times wormwood. Myrrh and frankincense are most often burned in spells which require a vision or the inquiry of a lamp.

PGM 4.3 I72-3208 is a spell for producing a dream; it expects the vision to come at night in the user's dreams. Accordingly, the ingredients are meant to produce sleep. The spell asks the user to burn frankincense lumps, and while completing the procedure, to ask the lamp to send a dream concerning a particular matter.

PGM 7.628-42 is a spell for receiving divination from Asclepius, likely for a medical cure. For the spell to work, the user is instructed to burn three grains of frankincense in the same place where he sleeps and to move a metal ring through the smoke.

PGM 7.795-845 is a spell for a dream divination and boasts its lineage from the philosophers Pythagoras and Democritus.34 For three nights the user must burn frankincense and speak a formula. Before the expected divination, he must burn incense over a laurel branch and go to sleep with it on his head.

PGM 8.64-I IO is a spell for a dream oracle. The user must draw a creature called Besa on his hand, cover it in cloth, and go to sleep. The ink used includes myrrh and wormwood and would soak through his skin.

Vessel and lamp inquiries make up the next set of examples. These visions would happen while awake and in a trance. PGM 7.319-734 is a spell for a direct vision. It requires burning male frankincense while making an inquiry of a copper vessel. PDM I $4.805-40$ is a spell for a vessel 
inquiry. It uses many botanical materials which are listed in code words, including myrrh. The end product is two different eye ointments which must be applied depending on whether the user undergoes divination alone or uses another person, a pure youth. PGM $7 \cdot 505-28$ is a spell for meeting one's daimon. It requires the user to write a name on two eggs with myrrh ink and to lick off the name from one of the eggs.

\section{CONCLUSION: DID MAGIC WORK?}

THESE SPELLS in many ways constitute the private spirituality of a magician with clients to serve or for the client-users alone. The users of these different spells felt that something magical had occurred. One would experience for a certain period of time an altered state of consciousness, a hypnotic or narcotic state, and perhaps vivid dreams. If the spells did not produce the desired result, i.e., the women did not come or the chosen chariot did not win the race, then it was not the user's lucky day. Because of the ingestion of botanical substances, the user still felt some magic had happened. If nothing ever occurred, the user might well not return to the place where the spell and ingredients were bought.

The different ingestion methods of these spells show us the various ways that the ingredients could find a way into the body in order to work: eating, drinking, licking, lip ointment, ear drops, transdermal and also sublingual application, and fumigation (through the lungs). The ecstatic experience was promised and delivered to the client. Besides sympathy as a magical rationale, the ingestion of ingredients allowed the magic to touch or come in contact with the user, to be inside them. The client must write magic, recite magic, touch magic, and ingest it.

It is important to note, however, that there are other visionary spells that either do not require any ingredients (the spells likely assume the client will supply ingredients) or the ingredients are present, but not ingested. In spells where 
there is no clear method of ingestion, the client may still come into contact with the potent botanicals while preparing the spell. And the client may already know to ingest some of the ingredients for it to work.

Since the practice of magic was somewhat "underground," especially in Late Antiquity, and since it relied on initiation, it contains language and terminology inclusive to those initiated and those practiced. This tendency puts those uninitiated at a disadvantage in interpreting the spells and their outcomes. Based on the collection's own warning, about code words for ingredients, we cannot be sure that we understand the ingredients listed as being such or the outcomes as being literal.

PGM I.42-195 gives us the clearest understanding of this. Applied to the rest of the vision spells, their outcomes were "half real and half imaginary." The ingredients produce mania and ecstatic states which in return fulfil the promise of the visionary spell. These spells, expensive and time-consuming, were used for spiritual and entertainment purposes.

A user would have felt something, while having an altered state of consciousness and this something may have made him feel better, in general and/or concerning a particular matter. Many of the visionary spells should be approached with the same mindset. In ancient Babylonian medicine concerning unrequited love, the patient was given a mind-altering drug and asked to speak an enchantment. It was supposed to make their soul feel better about the situation. 35 Pliny (2I.I05, 30.I) is skeptical about drug-induced religious and magical experiences, but he describes people taking drugs to feign divination and agrees that these plants caused hallucination and visions. Theophrastus, Pliny, and Galen typically rationalize the magical side of these types of experiences, but they acknowledge the potency of the ingredients used.

There is more research necessary to fully understand the role that these botanicals played in ancient Greek and Roman magic. In return, we gain a better understanding of 
certain aspects of ancient Greek and Roman culture, their individual spirituality, and recreational intoxication. The spells should be analyzed further for psychoactive plants. Other ingredients used in ancient magic and medicine, which are known to cause mind-altering states, include all types of rue, hellebore, certain mushrooms, ephedra, ergot, barley, darnel, nard, and cannabis. These items show up in the Greek and Roman world, going back to the ancient Greek Bronze Age, and they were used in other contemporaneous cultures, for instance the Near East, Persia, and Asia.

\section{NOTES}

I would like to thank the readers at Arion for their input and encouragement. I also thank my wife Sarah and dear friend Brian Rowe for their support. All translations in this essay are my own unless otherwise cited.

I. The following sources were important to my argument, analysis, and research. For ancient magic, its rationale, ingredients, and practice see the introduction and appendix to Georg Luck, Arcana Mundi (Baltimore 2006). The collection of ancient magic may be found in ancient Greek in the following source: A. Henrichs and K. Preisendanz, eds., Papyri Graecae Magicae Die Griechischen Zauberpapyri, 2nd edition (Stuttgart 1973-I974). The English translation along with introduction to the collection is found in H. Betz, ed., The Greek Magical Papyri in Translation (Chicago I992). For specific treatment of the Demotic parts of the collection see F. L. Griffith and H. Thompson, The Demotic Magical Papyrus of London and Leiden (London I904). Betz's collection in English translation contains both the ancient Greek and Demotic spells. For an introduction to the ingredients found in the collection and some rationale behind them, see J. Scarborough, "The Pharmacology of Sacred Plants, Herbs, and Roots," in C. Faraone and D. Obbink, eds., Magika Hiera (Oxford I99I).

2. This discussion is informed by the introduction to the English translation by Betz I992: xli-lviii (note I).

3. For a discussion of the several types of magicians and traveling drug dealers, see M. Rinella, Plato, Drug Culture, and Identity in Ancient Athens (Lanham, MD 2010), I77-78.

4. According to Pliny (I4.I9), these same herbs were commonly added to wine to increase its psychoactive potency.

5. There are sections in the magical papyrus (PGM 4.2963-3002) about picking herbs. Pliny (20.5 I) and Theophrastus (9.8.I-8) discuss the rootcutters as well as the dangers in picking plants.

6. They all contain powerful psychoactive alkaloids. See S. Funayama and G. Cordell, Alkaloids: A Treasury of Poisons and Medicines (London 
20I 5), page Io for a short discussion of alkaloids in ancient times and their use, pages I 8-20 for many ingredients in this essay. See D. C. A. Hillman, Chemical Muse (New York 2008), the appendix in Luck (note I), as well as Rinella (note 3 ) for other discussions.

7. The text for Galen comes from C. G. Kühn, Clandii Galeni opera omnia, vol. I9 (Hildesheim I965).

8. See Luck (note I, $483_{3}-84$ ) for a discussion of this passage and page 484 for his explanation of ecstatic states.

9. See M. Rinella (note 3, 36) for a discussion of these terms in the ancient sources.

Io. For the text of Dioscorides, I use M. Wellmann, Pedanii Dioscuridis Anazarbei de materia medica libri quinque (Berlin 1958) and I consult an English translation by L. Beck, tr., Pedanius Dioscorides of Anazarbus De materia medica (Hildesheim 2005).

I I. Luck (note I, 7-8, 482-86) cites examples where the ancient writer assumes that fumigation was associated with an ecstatic experience. See Rinella (note 3, 3I) for another discussion.

I 2. Luck (note I, 479) writes, "Magic is, in a way, a business transaction between the practitioner and the client. The client wants results, and he wants them here and now."

I3. Dioscorides (5.94) writes that cinnabar, often used as an ink, was very rare and expensive. Pliny (29.24) says that it is often mislabeled at the marketplace and substituted with cheaper ink ingredients.

I4. See the introduction to M. Rinella (note 3 ) for a discussion of ancient wine making, these same ingredients in wine, and their effects on the user. Also see P. McGovern, Uncorking the Past: The Quest for Wine, Beer, and other Alcoholic Beverages (Princeton 2009), for a discussion about ancient wine ingredients as well as the ancient grog, a psychoactive multi-ingredient drink commonly used in the Bronze Age around the Mediterranean Sea. These intoxicating drinks contained the same ingredients as the magical spells covered in this essay. I emphasize again that these ingredients appear in Bronze Age medicine, Classical Greece (Hippocratic Corpus through Theophrastus), the Roman Empire (Pliny, Dioscorides, Galen, and others), and into modern Europe.

I 5. The ancient Greek text comes from Sir Arthur Hort, Theophrastus Enquiry into Plants (Cambridge, MA I96I).

I6. Pliny (27.II9) shares a similar concept of drug tolerance.

I7. Galen (Omnia Opera I4.30) was rather suspicious of the drug dealers in Rome and would travel to the edges of the empire to procure his own ingredients. They didn't know their own products and adulterated them for quicker and more profitable sales. Pliny (NH 29.2 I-24) was also critical of the market dealers for similar reasons (29.7-9, 29.2I-22).

I8. See L. LiDonnici, "Single-Stemmed Wormwood, Pinecones and Myrrh: Expense and Availability of Recipe Ingredients in the Greek Magical Papyri," Kernos I4 (Varia 200I), 6I-9I for a discussion of many of 
these ingredients, theirs costs, and their associations with visionary spells. See also J. Scarborough, "Drugs and Medicines in the Roman World," Expedition 38 (2, I996), 38-52 for the costs of these ingredients.

I9. See M. Irwin, "Flower Power in Medicine and Magic: Theophrastus' Response to the Rootcutters," Mouseion (Series III, 6, 2006), 423-37 and V. Nutton, "The Drug Trade in Antiquity," Journal of the Royal Society of Medicine 78 (I985), I38-45 for a discussion of itinerant pharmacists, rootcutters, drug dealers, and the incense trade routes. See J. Scarborough, "Drugs and Drug Lore in the Time of Theophrastus, Folklore, Magic, Botany, Philosophy and the Rootcutters," Acta classica 49 (2006), I-30 for a similar discussion.

20. LiDonnici (note I 8 ), 82.

2I. See Hillman for a discussion, (note 6), 43, 80-83. Pliny, Dioscorides, and Theophrastus mention this psychoactive plant.

22. The Demotic Magical Papyri are written in Demotic and Coptic. The plant names and dosages tend to be in ancient Greek. It is unclear whether the Demotic spells are originally Egyptian magic or Greek magic copied into Demotic. See introduction to Griffith and Thompson (note I) for a discussion.

23. See J. Scarborough, "The Opium Poppy in Hellenistic and Roman Medicine," in Porter, R. and M. Tuech (eds.), Drugs and Narcotics in History (Cambridge I995), 4-23 and Hillman (note 6), Rinella (note 3) for discussions of opium in the ancient Greek and Roman world. See M.D. Merlin, "Archaeological Evidence for the Tradition of Psychoactive Plant Use in the Old World," Economic Botany 57 (3, 2003), 295-323 for a discussion of opium and other psychoactive ingredients in all ancient civilizations. Pliny (20.76) writes about opium in many sections. Galen and almost every other ancient writer mentions the drug, including literary genres.

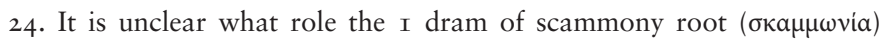
would play in the recipe and outcome. Dioscorides (4.I70.3) writes that I dram milk from the root is a fine dosage for medical application. It (4.I70.4) can be used as a salve to alleviate chronic headaches.

25. Theophrastus (9.9.I) and Pliny (I4.I9, 25.94) discuss mandrake and its narcotic properties. It appears commonly throughout ancient medical writings and modern ones.

26. Pliny (25.17) notes the psychotropic properties of henbane, as do other writers.

27. These line numbers correspond to Betz's edition (note I). When the Greek is cited, then it corresponds to the original collection of papyri (note I). The two documents do not always line up.

28. There are many ancient references to myrrh in ancient magic, medicine, and wine production. Scholars, for instance McGovern (note I4), cover its history in wine and medicine. Theophrastus gives us the earliest investigation to its importation and preparation in distant foreign lands. Pliny (24.I02), in a discussion about Democritus' writings of drugs that 
cause visions, talks about a wine made by the Scythians in Bactria containing cannabis and myrrh.

29. See Hillman (note 6, 53, 73-75, I22) for a discussion of wormwood. LiDonnici (note I3, 83-89) also covers wormwood. Today, wormwood is typically called absinth and it is put in alcoholic drinks. Pliny (27.28) says that wormwood causes sleep, if inhaled through the nose. It was commonly used in the ancient world, especially for its intoxicating effects. See McGovern (note I4, I38-39) for another discussion.

30. Dioscorides $(4.42)$ writes that it was used for religious purification, religious sacrifices, and religious observations.

3I. Theophrastus (9.II.5-6) writes: "of the nightshade one causes sleep

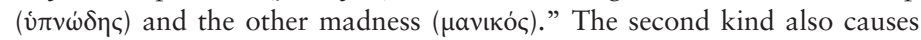

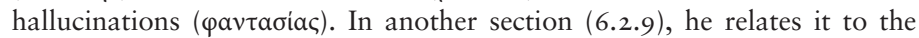
effects of wine. Pliny (2I.IO5) discusses nightshade and says that people used it to induce magical visions. It was also employed in ancient medicine. See pages I 27-30 in C. Faraone, Ancient Greek Love Magic (Cambridge, MA I999) for a discussion of this passage, the drug, and other similar ingredients in love magic.

32 See Hillman (note 6) for a discussion on rose oil and psychoactive volatile oils in general.

33 Roman emperors had the best imported drugs. Galen (Omnia Opera I4.2II) describes special imperial rootcutters in Crete who were employed by the emperor and ensured the royal supply.

34 Pliny $(24.102,25.5)$ often cites the works of these two philosophers in his discussion of plants and their psychoactive properties.

35 See M. Geller, Ancient Babylonian Medicine: Theory and Practice (West Sussex 2010), 37, for a discussion. 
INSIDE THIS IsSUE:

Aeneas meets Anchises: DAvid FerRY translates from the Aeneid

A reading of the Odyssey, book 6, by Norman Austin

Brian Walters in the voice of Propertius

Roberto Bolaño harasses Horace, by IAN FieLDing

Horace counts his blessings, translations by KaRL JOHNSON

Colin Cromwell Pang on Catullus, Hip-hop, and masculinity

"Statue" and "Shapeshifter," poems by Margaret Wack

Alan Sumler discusses the ingredients and ecstasies in the Magical Papyri

JoAn Kimball’s "Visitation" and "Perpetual Notion"

Joseph Russo and BennetT Simon on winning, losing, and success in Herodotus

Two poems by LaWrence Dugan

From Karl Kirchwey's Mutabor: "Palmyra" and "Colosseum"

Comedy and Tragedy in Modern Politics:

Louis A. Ruprecht JR. reviews Angus Fletcher's

Comic Democracies: From Ancient Athens to the American Republic

On Black Ground: Helaine L. Smith on the Berlin Painter at the Princeton University Art Museum 